\title{
Molecular and cellular mechanisms for microbial entry into the CNS
}

\author{
Jing-Ren Zhang ${ }^{1}$ and Elaine Tuomanen ${ }^{*, 1}$ \\ ${ }^{1}$ Department of Infectious Diseases, St. Jude Children's Research Hospital, 332 North Lauderdale Street, Memphis, \\ Tennessee, TN 38105, USA
}

\begin{abstract}
A number of pathogenic microbes including neuroinvasive viruses, bacteria and parasites are capable of entry into the central nervous system (CNS) and cause a variety of clinical manifestations. The cellular and molecular mechanisms for the CNS invasion have been extensively studied in the last two decades. Viruses invade neurons and thereby cause encephalitis or peripheral neuritis, while bacteria enter the cerebrospinal fluid (CSF) and cause meningitis. In contrast, the mechanisms for parasitic neuroinvasion are much more complex and less clear. The capabilities that enable these elite subsets of pathogens to engineer uptake into the CNS will be the subject of this review.
\end{abstract}

Keywords: neuroinvasion; blood-brain barrier; pathogenesis

\section{Protection of the CNS across the blood-brain barrier}

To understand the CNS invasion process by neuroinvasive microbes, it is necessary to describe one of the defensive structures in the CNS that prevent microbial invasion. The CNS is sequestered from the systemic circulation by the blood-brain barrier (BBB). At the anatomic level, the BBB refers to two different but connected structures: a barrier between blood and brain in cerebral capillaries and a barrier between blood and CSF in choroid plexus (Brightman, 1989). The former is formed by intercellular tight junctions between brain microvascular endothelial cells (BMEC). The BMEC layer is supported by astrocytes, pericytes and the basement membrane (Figure 1A).

The BMEC differs from the fenestrated peripheral endothelium in two important aspects. First, tight junctions between the BMEC possess extremely strong electrical resistance (Crone and Olesen, 1982), which restricts the amount of paracellular flux. Second, the BMEC has a relatively low number of pinocytotic vesicles and thus undergoes a slow rate of fluid-phase endocytosis (Reese and Karnovsky, 1968), which restricts the amount of transcellular flux. In combination, the cerebral capillaries

${ }^{*}$ Correspondence: E Tuomanen

Received 6 April 1999; revised 13 July 1999; accepted 16 July 1999 are highly resistant to passage of ions and small molecules such as dyes and antibiotics. Instead, specific transport systems are utilized to provide essential substances such as glucose, ions and amino acids across the barrier to support neuronal function. The energy cost of the active transport system is accompanied by a relatively high number of mitochondria.

In localized areas of choroid plexus within each of the four cerebral ventricles, the permeability of the cerebral capillaries is dramatically increased due to fenestration of the BMEC layer. A highly vascularized epithelium serves as a barrier function between blood and CSF (Figure 1B). Although the polarized choroid plexus epithelium is able to form tight junctions, the epithelial tight junctions have lower electric resistance than those of the BMEC (Zeuthen and Wright, 1981). This allows passage of some blood components across the BBB to form CSF, but exposes a weak area for microbial penetration into the CSF space. The site of microbial entry into the subarachoroid space has not been definitely identified, but choroid plexus is a leading candidate.

Neuroinvasive microbes can infect numerous brain tissues and cause a variety of clinical manifestations from viral encephalitis to bacterial meningitis, suggesting broad penetration capability across the BBB. We have selected some of the 
typical cases to illustrate the principal cellular mechanisms by which viral and bacterial pathogens invade the CNS.

\section{Strategies of CNS invasion by viruses}

Viral pathogens may invade the CNS through either the blood circulation or the peripheral nerve route (Johnson, 1982; Tyler and Gonzalez-Scarano, 1997). There are at least four different mechanisms by which viruses traverse the BBB into the CNS. First, blood-borne viruses may gain access to the CNS by infecting the BMEC or may be transported across the BMEC (Johnson, 1982). Infection of the BMEC may provide a portal for viral entry into the CNS and disrupt the BBB function. A number of viruses such as cytomegalovirus (Lathey et al, 1990), human immunodeficiency virus (HIV) (Moses et al, 1993, 1996), and arboviruses (Dropulic and Masters, 1990) are able to infect the BMEC in vitro. Infection of the BMEC has also been demonstrated in vivo by detecting viral nucleic acid (Bagasra et al, 1996; Zurbriggen and Fujinami, 1988) or viral antigen (Mankowski et al, 1994) in cerebral capillaries of the infected individuals. Evidence suggests that canine distemper virus (Coffin and

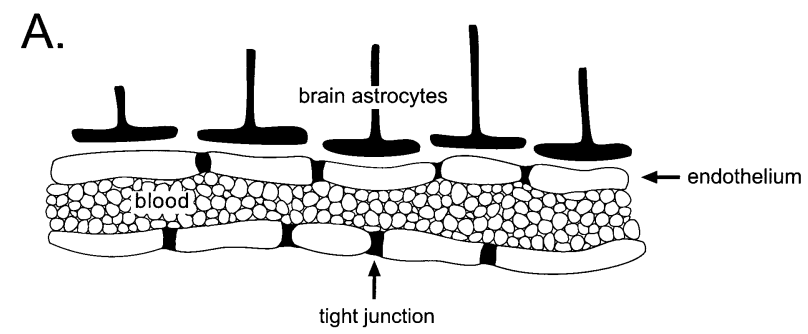

B.

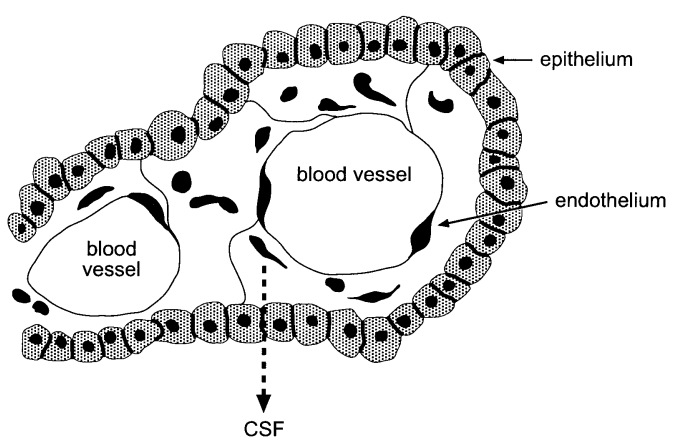

Figure 1 Schematic illustration of the BBB structures at (A) the cerebral capillary endothelium and (B) the choroid plexus. Tight junctions of the cerebral capillary endothelium prevent the blood elements from penetration into the CNS. The endothelial barrier is supported in part by brain astrocytes. At the choroid plexus, the endothelial layer of the blood vessels is fenestrated to allow penetration of the blood contents, but the epithelium surrounding the blood vessels serves as a barrier between blood and CSF.
Liu, 1957) and Semiliki Forest virus (Pathak and Webb, 1974) can be directly transported to the CNS through the BBB.

Second, viruses may transmigrate across the BBB within virally infected leukocytes. Lymphocytes have been implicated to carry canine distemper virus across the BBB (Summer et al, 1978). Studies also suggest that HIV enters the CNS by shedding from infected $\mathrm{CD}^{+} \mathrm{T}$ cells, macrophages, and microglia during migration through the BBB (Nottet et al, 1996; Peluso et al, 1985; Persidsky et al, 1997; Schmidtmayerova et al, 1996). A variety of host adhesion molecules have been shown to enhance entry of the virally infected leukocytes into the CNS (Brankin et al, 1995; Soilu-Hanninen et al, 1997). These include intercellular adhesion molecule 1 (ICAM-1) (Adamson et al, 1999; Shrikant et al, 1996), vascular cell adhesion molecule 1 (VCAM-1) (Sasseville et al, 1994, 1995) and leukocyte function antigen 1 (LFA-1) (Attibele et al, 1993; Hildreth and Orentas, 1989). Related to this mechanism, leukocytes may facilitate viral entry into the CNS by producing inflammatory substances, which can in turn affect permeability of the BBB. For example, $\mathrm{TNF} \alpha$ has been demonstrated to promote HIV entry into the CNS by disrupting paracellular tight junctions of the BBB (Fiala et al, 1997). Consistent with these findings, bacterial lipopolysaccharide (LPS), a potent inducer of cytokines, has been found to enhance penetration of Sindbis virus into the CNS (Lustig et al, 1992).

Third, viruses can also penetrate the CNS by taking advantage of incomplete closure of the BBB (Johnson, 1982). Despite the intercellular tight junctions between the capillary endothelial cells in most regions of the BBB, certain areas of the CNS such as the choroid plexus, posterior pituitary, and circumventricular organs are not completely protected by the BBB due to a fenestrated endothelial cell layer and sparse basement membrane. A number of blood-borne viruses including mumps virus (Herndon et al, 1974), HIV (Bagasra et al, 1996; Falangola et al, 1995; Harouse et al, 1989), and rat parvovirus (Lipton and Johnson, 1972) have been suggested to penetrate across the choroid plexus microvessels and infect the epithelium, suggesting that these viruses may enter the CSF space. In the CSF space, viruses can subsequently infect the ependymal cells and surrounding brain tissue.

Finally, viruses can spread to the CNS through peripheral intraneuronal routes (Tyler and Gonzalez-Scarano, 1997). The motor neurons of the spinal chord and some primary sensory neurons are directly connected to the CNS, thus providing a convenient route for neurotropic viruses (Johnson, 1982). Viruses including herpes simplex virus (Johnson, 1964), pseudorabies virus (Rziha et al, 1986), and rabies virus (Murphy, 1977) are able to replicate within peripheral nerves and are trans- 
ported into the CNS through the axonal transport system of neurons. Certain enteroviruses can even spread to the CNS by infecting enteric neurons (Morrison and Fields, 1991; Morrison et al, 1991).

\section{Strategies of CNS invasion by bacteria}

A number of bacteria are capable of invading the CNS and cause bacterial meningitis (Overturf, 1994). However, the majority of bacterial meningitis cases are caused by Streptococcus pneumoniae, Neisseria meningitidis, and Haemophilus influenzae, and in the newborn Escherichia coli and Group B streptococcus. The ability to cause true neuritis or encephalitis is much more rare in bacteria as exemplified by leprosy, Lyme disease and syphilis. In contrast to the advanced knowledge in cellular and molecular mechanisms of viral neuroinvasion (Tyler and Gonzalez-Scarano, 1997), current understanding of bacterial counterparts is still sketchy. Except for special conditions such as brain injuries due to trauma or neurosurgery, neuroinvasive bacteria enter the CNS by blood-borne infection (Ring and Tuomanen, 1997). These pathogens multiply to high densities in the blood, with the level of bacteremia correlating with the risk of CNS penetration. When bacteria reach the luminal side of the cerebral capillaries, there are several possible routes to enter the CNS (Tuomanen, 1996).

\section{Site of transversal}

The specific entry sites into the CNS are not known for most bacteria. $H$. influenzae appears to enter the CNS at the choroid plexus. In monkeys infected with $H$. influenzae, Daum et al (1978) found higher bacterial densities in the CSF of the ventricles compared to the lumbar space. Given the fact that the CSF flows unidirectionally from the ventricles down to the lumbar space, this finding suggests bacterial entry at the choroid plexus. This is consistent with the observation that plexitis is frequently observed in early meningitis. On the other hand, a recent study suggests that $N$. meningitidis cross the $\mathrm{BBB}$ at both the choroid plexus and the BMEC (Pron et al, 1997). N. meningitidis was found to attach to the endothelium of the choroid plexus and the meninges in a patient with meningitis. Pilusmediated adhesion appears to be required for bacterial attachment to the BMEC (Pron et al, 1997). Other bacteria including E. coli (Huang et al, 1995), Listeria monocytogenes (Parida et al, 1998; Wilson and Drevets, 1998), Group B streptococcus (Nizet et al, 1997), and S. pneumoniae (Ring et al, 1998) have been demonstrated to adhere to and invade the BMEC in vitro. This suggests that these bacteria may transverse the $\mathrm{BBB}$ at the choroid plexus to infect CSF and may infect and transverse the BMEC.
Pathway of transversal

Current knowledge suggests that bacteria transmigrate the BBB by at least two pathways: paracellular penetration and transcellular migration (Figure 2). E. coli (Huang et al, 1995), L. monocytogenes (Parida et al, 1998; Wilson and Drevets, 1998), and Group B streptococcus (Nizet et al, 1997) invade the BMEC in vitro, suggesting that transendothelial migration serves as an invasion mechanism for these pathogens. Consistent with this notion, Ring et al (1998) have recently demonstrated that $S$. pneumoniae is able to transmigrate across human BMEC. Evidence has suggested that host receptors are required to mediate the transendothelial migration process. Platelet-activating factor (PAF) receptor can promote transendothelial migration by $S$. pneumoniae by interacting with pneumococcal phosphorylcholine (Cundell et al, 1995; Ring et al, 1998). In a similar fashion, E-cadherin is required for invasion of epithelial cells by L. monocytogenes (Mengaud et al, 1996), although its role in endothelial transmigration is unclear. In contrast, Lyme disease agent Borrelia burgdorferi (Szczepanski et al, 1990) and syphilis bacterium Treponema pallidum (Haake and Lovett, 1994; Thomas et al, 1988) appear to cross the endothelial barrier by travelling between the endothelial cells.

\section{A.}
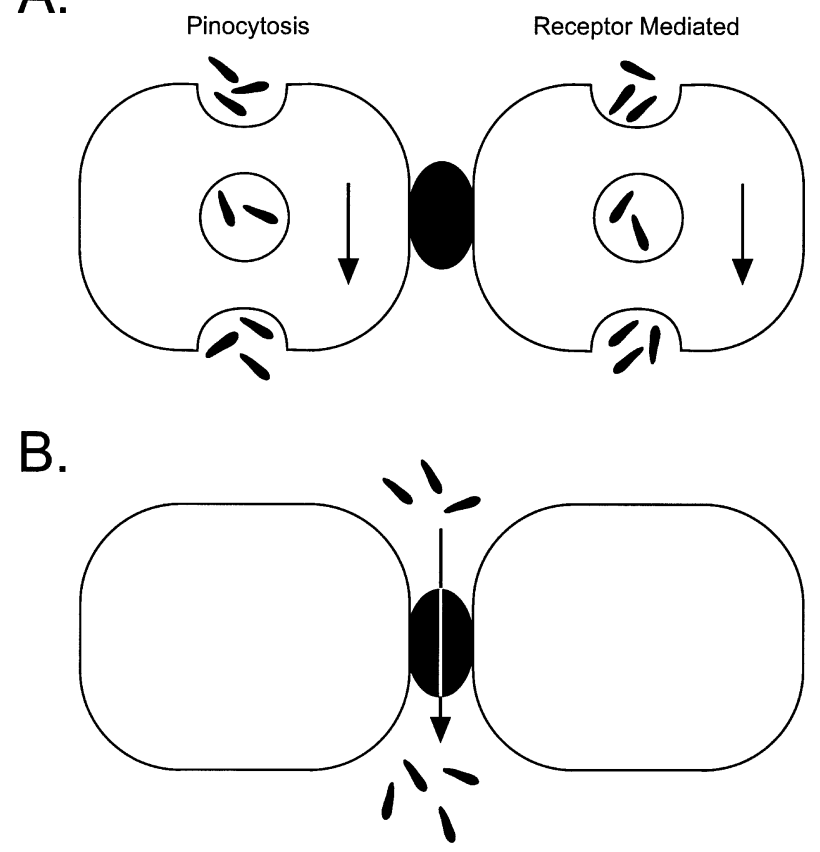

Figure 2 Bacterial passage across the BBB via (A) intracellular or (B) paracellular routes. Intracellular penetration is initiated by bacterial adherence to the blood vessels followed by bacterial entry into the capillary endothelium through pinocytotic or receptor-mediated mechanisms. In contrast, other bacteria may cross the BBB through tight junctions. Factors loosening or interrupting the tight junctions may facilitate paracellular penetration by bacteria. 
Bacterial products and the CNS invasion

BBB permeability can be modulated by bacterial components such as LPS (Patrick et al, 1992; Temesvari et al, 1993; Wispelwey et al, 1988), cell wall (Burroughs et al, 1992), and proteins (Spellerberg et al, 1995; Wispelwey et al, 1989). In a bacterial meningitis model, inoculation of animals with live $H$. Influenzae or bacterial LPS caused functional and ultrastructural changes of the BBB (Wispelwey et al, 1988, 1989). Release of these bacterial products during bacteremia could compromise the integrity of the BBB, which may facilitate bacterial entry into the CNS. Consistent with these findings, Lustig et al (1992) have shown that bacterial LPS facilitates viral neuroinvasion in a mouse model. Increased BBB permeability could be a direct effect of these bacterial products on the BBB or an indirect effect of host inflammatory mediators such as nitric oxide (Jaworowicz et al, 1998), TNF $\alpha$ and IL-1 (Mun-Bryce and Rosenberg, 1998).

\section{Strategies of CNS invasion by fungi and parasites}

A number of fungal and parasitic pathogens can infect the CNS and cause a variety of neurological complications. Several examples are discussed here to illustrate the principles of CNS invasion by these pathogens. Candida albicans and Cryptococcus neoforman are the leading causes of neuroinvasive fungal infections, particularly in immunocompromised hosts (Casadevall and Perfect, 1998; Odds, 1988). Although, the routes of CNS infections by fungal pathogens appear to be similar to viral and bacterial blood-borne infections, it is not clear how fungi overcome the BBB to enter the CNS. $C$. albicans is able to bind to a variety of brain cell types including the BMEC, microglia, and neurons (Blasi et al, 1991; Denaro et al, 1995). Similarly, studies have shown that $C$. neoforman can invade vascular endothelium (Ibrahim et al, 1995) and a variety of brain cells (Gomes et al, 1997; Lee et al, 1995). Available evidence suggests that neuroinvasive fungi are capable of entry into the CNS by invasion of the BMEC.

Neuroinvasive parasites gain access to the CNS via blood circulation. The mechanisms for subsequent entry of parasite pathogens across the BBB are poorly understood. Toxoplasma gondii, causing severe encephalitis in immunocompromised hosts, is able to attach to and invade a wide range of vertebrate nucleated cells (Sibley, 1995). The ability of T. gondii to invade microglia (Fischer et al, 1997) and BMEC (Gay-Andrieu et al, 1999) suggest that $T$. gondii may enter the CNS by transmigrating the BBB. In sharp contrast to $T$. gondii, malaria Plasmodium parasites primarily invade reticulocytes, particularly erythrocytes. Thus, cerebral malaria does not appear to be caused by parasitic invasion in the CNS. However, Plasmodium parasites are evolved to modify the surface of the infected erythrocytes (Howard, 1988; Smith et al, 1995). The modified erythrocytes acquire ability to adhere to the BMEC and uninfected erythrocytes (Dobbie et al, 1999; Ockenhouse et al, 1992b), which has been postulated to contribute to the pathogenesis of cerebral malaria (Aikawa, 1988; Miller et al, 1994). Plasmodium-infected erythrocytes adhering to the BMEC lead to increased permeability, progressive deterioration and breakdown of the BBB (Hermsen et al, 1998; Polder et al, 1992; Thumwood et al, 1988).

\section{Molecular and genetic determinants of microbial neuroinvasion}

To invade the CNS, pathogens need to replicate in the peripheral organs and/or blood and then specifically interact with the host CNS cells. A number of microbial molecules have been demonstrated to enhance neuroinvasion in animal models or cell cultures (Ring and Tuomanen, 1997; Tyler and Gonzalez-Scarano, 1997). A few examples are selected here to illustrate the potential roles played by these microbial molecules.

\section{Viral envelope proteins}

Viral envelope proteins have been shown to play an important role in neuroinvasion of some viral pathogens as exemplified by HIV-1 glycoprotein gp120 (Turner and Summers, 1999). AIDS dementia complex is caused by HIV-1 infection of the CNS (Kolson et al, 1998). Numerous studies have shown that the HIV-1 gp120 is essential for the CNS entry of HIV-1 (Kolson et al, 1998). gp120 has been clearly shown to bind to the CD4 receptor and other coreceptors in non-endothelial cells (Berger, 1998), but this protein has not been well described in terms of its interaction with BMEC receptors. Glycosylated recombinant gp120 can be taken up by the BMEC and transported across the BBB into brain tissue (Banks et al, 1997). Based on available information, gp120 may mediate HIV-1 transversal across the $\mathrm{BBB}$ by enhancing the migration of infected leukocytes across the BMEC (Hurwitz et al, 1994), modulating the BBB permeability (Annunziata et al, 1998), or enabling viruses to invade and infect the BMEC (Kolson et al, 1998). Since the BMEC does not express the principal CD4 receptor (Moses et al, 1993), it is postulated that gp120 interacts with the chemokine receptors and/or other unknown receptor(s) expressed on the BMEC.

Mosquito-borne infection by bunyaviruses causes pediatric encephalitis (Griot et al, 1994). The middle segment of the bunyavirus genome encodes two surface glycoproteins that determine the ability of the viruses to invade the CNS in a mouse model 
(Janssen et al, 1984, 1986). Another example is the E2 glycoprotein of Sindbis virus. E2 is required for neuroinvasion in infected mice, since single amino acid substitutions can abolish neuroinvasiveness (Davis et al, 1986; Dubuisson et al, 1997). Although the exact roles played by these viral envelope proteins in neuroinvasion are not clear, it is possible that these proteins are involved directly or indirectly in receptor binding (Pekosz et al, 1995; Tucker et al, 1993) and/or cellular penetration (Davis et al, 1986).

\section{Other viral components}

Viral polymerase has been shown to be associated with neuroinvasiveness in bunyaviruses (Griot et al, 1993, 1994). Mutations in viral polymerase resulted in an avirulent phenotype (Griot et al, 1993). It is not clear how the viral polymerase enhances neuroinvasion. Finally, neuroinvasiveness has been mapped to unexpected regions of viral genomes, including non-coding sequences in poliovirus (Macadam et al, 1994) and Sindbis virus (Dubuisson et al, 1997). It has been suggested that sequences in these regions are critical for formation of stem-loop structures, which are required for efficient translation of viral genes (Skinner et al, 1989; Strauss and Strauss, 1994).

\section{Bacterial molecules}

The molecular determinants of neuroinvasive bacteria are not well understood. Two examples with molecular information are $E$. coli and $S$. pneumoniae. Several surface structures of $E$. coli K1 have been extensively studied in terms of BMEC invasion. The filamentous S-fimbrae appears to be a key virulence factor involved in neonatal meningitis (Korhonen et al, 1985; Parkkinen et al, 1988). Two S-fimbrae proteins, SfaA and SfaS, have been shown to enhance $E$. coli K1 attachment to the BMEC by binding to sulfated glycolipids (Prasadarao et al, 1993) and terminal sialyl-2,3-galactose epitopes of glycoproteins (Stins et al, 1994), respectively. A major outer membrane protein designated OmpA is able to bind to $\mathrm{N}$-acetylglucosaminyl1-4N-acetylglucosamine structures expressed on BMEC glycoproteins (Prasadarao et al, 1996a) and thereby promote E. coli invasion (Prasadarao et al, 1996b). More recently, a small E. coli protein called Ibe10 has been identified to be essential for $E$. coli invasion of the BMEC (Huang et al, 1995). Ibe10 appears to interact with an albumin-like protein on the surface of the BMEC (Prasadarao et al, 1999). Unlike OmpA which is expressed by both clinical and nonclinical isolates (Prasadarao et al, 1996b), Ibe10 is expressed only in clinical $E$. coli $\mathrm{K} 1$ isolates, but not in laboratory strains of E. coli K12 (Huang et al, 1995). Therefore, the Ibe10 protein appears to be a specific determinant of the BMEC invasion. Thus, four proteins promote the interaction of $E$. coli $\mathrm{K} 1$ with the
BMEC and their relative roles are yet to be determined.

Several pneumococcal surface molecules including phosphorylcholine and choline binding protein A (CbpA) have been identified to be important for BMEC invasion and transmigration (Ring et al, 1998). Endothelial cell surface oligosaccharide LnNT has been suggested to bind to pneumococcal CbpA (Rosenow et al, 1997). Pneumococcus strains undergo spontaneous phase variation that changes the amount of these invasive determinants on the bacteria (Weiser et al, 1994). In a two-chamber model, variants bearing more CbpA and phosphorylcholine were able to invade human BMEC and subsequently transmigrate across BMEC monolayer to the basolateral side, whereas counterparts without these determinants were predominantly recycled back to the apical side (Ring et al, 1998). Phosphorylcholine appears to participate in the BMEC invasion by directly interacting with the PAF receptor (Cundell et al, 1995) and anchoring a family of choline-binding proteins including CbpA to the pneumococcal surface (Tuomanen and Masure, 1997).

Bacterial cell wall components such as LPS in E. coli and $H$. Influenzae (Patrick et al, 1992; Temesvari et al, 1993) and glycoproteins from $S$. pneumoniae (Spellerberg et al, 1995) have been known to affect BBB permeability. Release of these substances during bacteremia may facilitate bacterial entry into the CNS. Meningococcal LPS and several surface proteins including pilin, Opa, Opc, and PilC have been known to bind to a variety of host cellular receptors (Jerse and Rest, 1997). A specific role in CNS invasion has been suggested for PilC (Pron et al, 1997). In contrast, little is known about molecular basis of CNS invasion in $L$. monocytogenes, although a number of virulenceassociated proteins have been identified in this pathogen (Cossart and Lecuit, 1998).

\section{Fungal and parasitic factors}

Adherence and invasion of host tissues by fungi and parasites depend on cells surface structures. $C$. albicans surface proteins including integrin-like protein (Int1) and hypha-specific surface protein (Hwp1) are required for virulence and fungal adherence to epithelial and endothelial cells (Gale et al, 1998; Gozalbo et al, 1998; Staab et al, 1999). Other C. albicans proteins such as ALA1 (Gaur and Klotz, 1997) and glyceraldehyde-3-phosphate dehydrogenase (GAPDH) (Gozalbo et al, 1998) have been reported to mediate adherence of the fungus to various extracellular matrix proteins. Another set of C. albicans cell wall proteins have been implicated in adherence to host tissues (Kanbe and Cutler, 1998), but these proteins require O-mannosyl modification for adhesin activity (Buurman et al, 1998; Timpel et al, 1998). Mannoproteins are also involved in cytoadherence of $C$. neoformans 
(Hamilton and Goodley, 1996). Finally, C. neoformans capsule influences fungal invasion of vascular endothelium (Ibrahim et al, 1995). The specific roles of these fungal surface proteins in neuroinvasion have not been determined.

The actin cytoskeleton of $T$. gondii is necessary for host cell invasion (Dobrowolski and Sibley, 1996). Despite lack of evidence, the parasitic cytoskeleton is likely to be also involved in host invasion of other protozoan parasites. Significance of parasitic proteins in adherence has been clearly demonstrated with a Plasmodium protein, designated erythrocyte membrane protein 1 (PfEMP1). PfEMP1, an antigenic variant protein encoded by a family of var genes (Baruch et al, 1995; Su et al, 1995), is among numerous Plasmodium proteins exported to the membrane of the infected cells (Howard, 1988; Smith et al, 1995). PfEMP1 binds to multiple host receptors including CD36, thrombospondin, ICAMI, and chondroitin sulfate A expressed on the BMEC (Baruch et al, 1996; McCormick et al, 1997; Reeder et $a l, 1999)$. PfEMP1 is also able to specifically interact with complement-receptor 1 (Rowe et al, 1997) and heparan sulfate (Chen et al, 1998) expressed on uninfected erythrocytes. PfEMP1-mediated adherence of the infected erythrocytes to vascular endothelium and uninfected erythrocytes leads to phenomena known as sequestration and rosetting, respectively, which are considered to contribute to manifestations of cerebral malaria (Fernandez et al, 1998; Miller et al, 1994).

\section{Host cellular receptors}

A number of host factors ranging from oligosaccharides and lipids to proteins have been identified to serve as receptors for neuroinvasive pathogens. Interestingly, single host molecules can serve as receptors for different pathogens. Three examples are the CD46, $\alpha$-dystroglycan, and ICAM-1 (Tables 1 and 2). CD46 binds to both lymphocytic choriomeningitis virus and $N$. meningitidis PilC; $\alpha$-dystroglycan serves as a receptor for both measles virus and M. leprae; Human rhinovirus and Plasmodium PfEMP1 specifically interact with ICAM-1, although the virus and parasitic protein bind to distinct sites of ICAM-1 molecule (Ockenhouse et al, 1992a).

\section{Viral receptors}

Among numerous viral receptors (Tyler and Gonzalez-Scarano, 1997) (Table 1), HIV-1 receptors have been most extensively investigated in terms of specific receptor interactions. HIV-1 infects nonendothelial cells by receptor-mediated absorptive endocytosis in a two-step process. The gp120 glycoprotein initially binds to either the CD4 receptor (Maddon et al, 1986) or the galactosylceramide binding site (Fantini et al, 1993), which in turn facilitates gp120 binding to heparin-sulfate- bearing chemokine receptors (Feng et al, 1996; Pleskoff et al, 1997). A recent study has suggested that HIV-1 invades the BMEC by a similar endocytotic mechanism (Banks et al, 1998). However, the BMEC does not express either CD4 receptor or galactosylceramide binding sites and HIV-1 penetrates the $\mathrm{BBB}$ in a CD4/galactosylceramide-independent manner (Moses et al, 1993). Despite absence of these receptors, gp120 appears to be critical for HIV-1 penetration across the BBB (Banks and Kastin, 1998; Hurwitz et al, 1994). Several chemokine receptors including CCR3, CCR5, and CXCR4 have been identified recently in the BMEC (Lavi et al, 1998). The CCR5 receptor has been shown to be essential for BMEC infection by simian immunodeficiency virus (SIV) (Edinger et al, 1997). However, the roles of these coreceptors in the CNS entry of HIV-1 have not been determined.

\section{Bacterial receptors}

Several molecules expressed in the BMEC have been shown to enhance transversal of $E$. coli across the BBB (Table 1). These host molecules range from glycolipids to proteins and are able to bind to E. coli surface structures including S-fimbrae and outer membrane proteins. The recently identified Ibe10binding protein (Ibe10R) is particularly interesting, since it is essential for E. coli invasion of the BMEC (Prasadarao et al, 1999). Similarly, the PAF receptor is necessary for pneumococcal invasion of the BMEC through interaction with phosphorylcholine expressed on the pneumococcal surface (Cundell et al, 1995; Ring et al, 1998). Laminin and $\alpha$ -

Table 1 Host cell receptors or factors for neuroinvasive viruses

\begin{tabular}{lll}
\hline Virus & Host receptor or factor & Reference \\
\hline Echovirus & Integrin & Bergelson et al, 1992 \\
& CD55 & Bergleson et al, 1994 \\
a-herpesvirus & HveA & Wontgomery et al, 1996 \\
& HveB & Geraghty et al, 1998 \\
& HveC & Maddon et al, 1986 \\
HIV-1 & CD4 & Edinger et al, 1998a,b \\
& Orphan receptor & Berger, 1998 \\
LCMV & Chemokine receptors & Cao et al, 1998 \\
Measles virus & CD46 & Dorig et al, 1993 \\
Poliovirus & Poliovirus receptor & Mendelsohn et al, 1989 \\
Rabies virus & Acetylcholine receptor & Superti et al, 1986 \\
& Gangliosides & Wunner et al, 1984 \\
& Phospholipids & Reagan and Wunner, \\
& 1985 \\
& Neural cell-adhesion & Thoulouze et al, 1998 \\
& molecule & \\
& Nerve-growth factor & Tuffereau et al, 1998 \\
& receptor & Greve et al, 1989 \\
ICAM-1 & Haywood, 1974 \\
Rhinovirus & Wangliosides & Wang et al, 1992
\end{tabular}

HIV-1=human immunodeficiency virus 1; ICAM-1=intercellular adhesion molecule 1; LCMV=lymphocytic choriomeningitis virus. 
Dystroglycan have been demonstrated to promote neural invasion of Mycobacterium leprae (Rambukkana et al, 1997, 1998), although the specific bacterial ligands have not been identified. Host receptors for other pathogens in CNS invasion remain to be investigated.

\section{Fungal and parasitic receptors}

Host receptors for fungi and parasites are poorly understood. Fibronectin, laminin, and vitronectin have been shown to mediate adherence of $C$. albicans to extracellular matrix (Forsyth et al, 1998; Klotz and Smith, 1991; Spreghini et al, 1999). Multiple host molecules expressed on the BMEC and erythrocytes bind to the Plasmodium PfEMP1 protein (Table 2). Interactions of PfEMP1 with CD36, thrombospondin, ICAM-I, and chondroitin sulfate A contribute to sequestration of Plasmodium-infected erythrocytes to the BMEC (Baruch et al, 1996; Reeder et al, 1999). Similarly, CD36, complement-receptor 1, and heparan sulfate of normal erythrocytes bind to PfEMP1 on the infected erythrocytes, leading to rosetting (Chen et al, 1998; Handunnetti et al, 1992; Rowe et al, 1997). Other host molecules have been implicated as receptors for Plasmodium-infected erythrocytes including VCAM-1, endothelial leukocyte adhesion molecule 1 (ELAM-1) (Ockenhouse et al, 1992b), and platelet/endothelial cell adhesion molecule 1 (PECAM-1/CD31) (Treutiger et al, 1997).

\section{Conclusion}

Despite the vast genetic diversity among neuroinvasive microbes, these pathogens face similar obstacles on the way into the CNS, and some share mechanisms for crossing the BBB. Most of these pathogens, however, use uniquely tailored routes, with viruses generally targeting brain parenchyma and bacteria targeting the CSF space. It is now clear that molecular interactions between the pathogens and the hosts determine the outcome of the infection. Our understanding of the molecular mechanisms of CNS diseases is still fragmentary.

\section{References}

Adamson P, Etienne S, Couraud PO, Calder V, Greenwood J (1999). Lymphocyte migration through brain endothelial cell monolayers involves signaling through endothelial ICAM-1 via a Rho-dependent pathway. J Immunol 162: 2964-2973.

Aikawa M (1988) Human cerebral malaria. Am J Trop Med Hyg 39: 3-10.
Table 2 Host cell receptors or factors for neuroinvasive bacteria, fungi and parasites

\begin{tabular}{|c|c|c|}
\hline $\begin{array}{l}\text { Bacterial } \\
\text { protein }\end{array}$ & Host receptor or factor & Reference \\
\hline \multicolumn{3}{|l|}{ E. coli } \\
\hline SfaA & Sulfated glycolipid & Prasadarao et al, 1993 \\
\hline SfaS & NeuAc-2, 3-Gal & Stins et al, 1994 \\
\hline OmpA & GlcNAc1-4GlcNAc & Prasadarao et al, 1996a \\
\hline Ibe10 & Ibe10R & Prasadarao et al, 1999 \\
\hline \multicolumn{3}{|c|}{ L. monoctyogenes } \\
\hline Internalin & E-cadherin & Mengaud et al, 1996 \\
\hline ActA & $\begin{array}{l}\text { Heparan sulfate } \\
\text { proteoglycan }\end{array}$ & $\begin{array}{l}\text { Alverez-Dominguez et al, } \\
1997\end{array}$ \\
\hline \multirow[t]{2}{*}{ M. laprae } & Laminin & Rambukkana et al, 1997 \\
\hline & $\alpha$-Dystroglycan & Rambukkana et al, 1998 \\
\hline \multicolumn{3}{|c|}{ N. meningitidis } \\
\hline Opc & Vitronectin & Virji et al, 1994 \\
\hline Opa & CD66 & Virji et al, 1996a,b \\
\hline PilC & CD46 & Kallstrom et al, 1997 \\
\hline \multicolumn{3}{|c|}{ S. pneumoniae } \\
\hline P-Choline & PAF receptor & $\begin{array}{l}\text { Cundell et al, 1995; Ring } \\
\text { et al, } 1998\end{array}$ \\
\hline \multirow{2}{*}{$\begin{array}{l}\text { CbpA } \\
\text { C. albicans } \\
\text { GAPDH }\end{array}$} & LnNT & Rosenow et al, 1997 \\
\hline & Fibronectin, laminin & P. falciparum \\
\hline \multirow[t]{6}{*}{ PfEMP1 } & Heparan sulfate & Chen et al, 1998 \\
\hline & Complement receptor 1 & Rowe et al, 1997 \\
\hline & CD36 & $\begin{array}{l}\text { Barnwell et al, 1989; } \\
\text { Baruch et al, } 1996\end{array}$ \\
\hline & Thrombospondin & $\begin{array}{l}\text { Baruch et al, 1996; } \\
\text { Roberts et al, } 1985\end{array}$ \\
\hline & ICAM-1 & $\begin{array}{l}\text { Baruch et al, 1996; } \\
\text { Berendt et al, } 1989\end{array}$ \\
\hline & Chondroitin sulfate A & $\begin{array}{l}\text { Reeder et al, 1999; Robert } \\
\text { et al, 1995; Rogerson et } \\
\text { al, } 1995\end{array}$ \\
\hline
\end{tabular}

P-Choline=phosphorylcholine; $\mathrm{PAF}=$ platelet-activating factor; GAPDH=glyceraldehyde-3-phosphate dehydrogenase.

Increasingly, identification of microbial virulence factors and host receptors will provide solutions for this complex puzzle. Understanding these capabilities will increase our ability to interrupt neuroinvasion in disease. However, it will also teach how to use these entry routes for therapeutic benefit, for example, for gene delivery of therapy of cancer and neurodegeneration disorders.
Alvarez-Dominguez C, Vazquez-Boland JA, CarrascoMarin E, Lopez-Mato P, Leyva-Cobian F (1997). Host cell heparan sulfate proteoglycans mediate attachment and entry of Listeria monocytogenes, and the listerial surface protein ActA is involved in heparan sulfate receptor recognition. Infect Immun 65: 78-88. 
Annunziata P, Cioni C, Toneatto S, Paccagnini E (1998) HIV-1 gp120 increases the permeability of rat brain endothelium cultures by a mechanism involving substance P. AIDS 12: 2377-2385.

Attibele N, Wyde PR, Trial J, Smole SC, Smith CW, Rossen RD (1993). Measles virus-induced changes in leukocyte function antigen 1 expression and leukocyte aggregation: possible role in measles virus pathogenesis. J Virol 67: 1075-1079.

Bagasra O, Lavi E, Bobroski L, Khalili K, Pestaner JP, Tawadros R, Pomerantz RJ (1996). Cellular reservoirs of HIV-1 in the central nervous system of infected individuals: identification by the combination of in situ polymerase chain reaction and immunohistochemistry. AIDS 10: $573-585$.

Banks WA, Akerstrom V, Kastin AJ (1998). Adsorptive endocytosis mediates the passage of HIV-1 across the blood-brain barrier: evidence for a post-internalization coreceptor. J Cell Sci 111: 533-540.

Banks WA, Kastin AJ (1998). Characterization of lectinmediated brain uptake of HIV-1 gp120. J Neurosci Res 54: $522-529$.

Banks WA, Kastin AJ, Akerstrom V (1997). HIV-1 protein gp120 crosses the blood-brain barrier; role of adsorptive endocytosis. Life Sci 61: L119-L125.

Barnwell JW, Asch AS, Nachman RL, Yamaya M, Aikawa M, Ingravallo $P$ (1989). A human 88-kD membrane glycoprotein (CD36) functions in vitro as a receptor for a cytoadherence ligand on Plasmodium falciparum-infected erythrocytes. $J$ Clin Invest 84: $765-772$.

Baruch DI, Gormely JA, Ma C, Howard RJ, Pasloske BL (1996). Plasmodium falciparum erythrocyte membrane protein 1 is a parasitized erythrocyte receptor for adherence to CD36, thrombospondin, and intercellular adhesion molecule 1. Proc Natl Acad Sci USA 93: 3497-3502.

Baruch DI, Pasloske BL, Singh HB, Bi X, Ma XC, Feldman M, Taraschi TF, Howard RJ (1995). Cloning the Plasmodium falciparum gene encoding PfEMP1, a malarial variant antigen and adherence receptor on the surface of parasitized human erythrocytes. Cell 82: $77-87$.

Berendt AR, Simmons DL, Tansey J, Newbold CI, Marsh $\mathrm{K}$ (1989). Intercellular adhesion molecule-1 is an endothelial cell adhesion receptor for Plasmodium falciparum. Nature 341: 57-59.

Bergelson JM, Chan M, Solomon KR, St. John NF, Lin H, Finberg RW (1994). Decay-accelerating factor (CD55), a glycosylphosphatidylinositol-anchored complement regulatory protein, is a receptor for several echoviruses. Proc Natl Acad Sci USA 91: 6245-6249.

Bergelson JM, Shepley MP, Chan BM, Hemler ME, Finberg RW (1992). Identification of the integrin VLA-2 as a receptor for echovirus 1. Science 255: $1718-1720$.

Berger EA (1998). HIV entry and tropism. When one receptor is not enough. Adv Exp Med Biol 452: 151157.

Blasi E, Mazzolla R, Barluzzi R, Mosci P, Bartoli A, Bistoni $F$ (1991). Intracerebral transfer of an in vitro established microglial cell line: local induction of a protective state against lethal challenge with Candida albicans. J Neuroimmunol 32: 249-257.
Brankin B, Hart MN, Cosby SL, Fabry Z, Allen IV (1995). Adhesion molecule expression and lymphocyte adhesion to cerebral endothelim: effects of measles virus and herpes simplex 1 virus. J Neuroimmunol 56: $1-$ 8.

Brightman MW (1989). The Anatomic Basis of the BloodBarrier. In: Implications of the Blood Brain Barrier and Its Manipulation. Neuwelt EA (ed). Plenum Publishing: New York, pp. 53-83.

Burroughs M, Cabellos C, Prasad S, Tuomanen E (1992) Bacterial components and the pathophysiology of injury to the blood-brain barrier: does cell wall add to the effects of endotoxin in gram-negative meningitis? J Infect Dis 165: S82-S85.

Buurman ET, Westwater C, Hube B, Brown AJ, Odds FC, Gow NA (1998). Molecular analysis of CaMnt1p, a mannosyl transferase important for adhesion and virulence of Candida albicans. Proc Natl Acad Sci USA 95: $7670-7675$.

Cao W, Henry MD, Borrow P, Yamada H, Elder JH, Ravkov EV, Nichol ST, Compans RW, Campbell KP, Oldstone MB (1998). Identification of alpha-dystroglycan as a receptor for lymphocytic choriomeningitis virus and Lassa fever virus. Science 282: 2079-2081.

Casadevall A, Perfect JR (1998) Cryptococcus Neoformans. American Society of Microbiology: Washington DC.

Chen Q, Barragan A, Fernandez V, Sundstrom A, Schlichtherle M, Sahlen A, Carlson J, Datta S, Wahlgren M (1998). Identification of Plasmodium falciparum erythrocyte membrane protein 1 (PfEMP1) as the rosetting ligand of the malaria parasite Plasmodium falciparum. J Exp Med 187: 15-23.

Coffin DL, Liu C (1957). Studies on canine distemper infection by means of fluorescein labeled antibody. II. Pathology of naturally occurring disease in dogs and antigenic nature of inclusion body. Virology 3: 132145.

Cossart P, Lecuit M (1998). Interactions of Listeria monocytogenes with mammalian cells during entry and actin-based movement: bacterial factors, cellular ligands and signaling. EMBO J 17: $3797-3806$.

Crone C, Olesen SP (1982). Electrical resistance of brain microvascular endothelium. Brain Res 241: 49-55.

Cundell DR, Gerard NP, Gerard C, Idanpaan-Heikkila I, Tuomanen EI (1995). Streptococcus pneumoniae anchor to activated human cells by the receptor for platelet-activating factor. Nature 377: 435-438.

Daum RS, Scheifele DW, Syriopoulou VP, Averill D, Smith AL (1978). Ventricular involvement in experimental Hemophilus influenzae meningitis. J Pediatr 93: $927-930$.

Davis NL, Fuller FJ, Dougherty WG, Olmsted RA, Johnston RE (1986). A single nucleotide change in the E2 glycoprotein gene of Sindbis virus affects penetration rate in cell culture and virulence in neonatal mice. Proc Natl Acad Sci USA 83: 67716775 .

Denaro FJ, Lopez-Ribot JL, Chaffin WL (1995). Adhesion of Candida albicans to brain tissue of Macaca mulata in an ex vivo assay. Infect Immun 63: 3438-3441. 
Dobbie MS, Hurst RD, Klein NJ, Surtees RA (1999). Upregulation of intercellular adhesion molecule-1 expression on human endothelial cells by tumour necrosis factor-alpha in an in vitro model of the blood-brain barrier. Brain Res 830: $330-336$.

Dobrowolski JM, Sibley LD (1996). Toxoplasma invasion of mammalian cells is powered by the actin cytoskeleton of the parasite. Cell 84: 933-939.

Dorig RE, Marcil A, Chopra A, Richardson CD (1993). The human CD46 molecule is a receptor for measles virus (Edmonston strain). Cell 75: 295-305.

Dropulic B, Masters CL (1990). Entry of neurotropic arboviruses into the central nervous system: an in vitro study using mouse brain endothelium. J Infect Dis 161: 685-691.

Dubuisson J, Lustig S, Ruggli N, Akov Y, Rice CM (1997). Genetic determinants of Sindbis virus neuroinvasiveness. J Virol 71: 2636-2646.

Edinger AL, Hoffman TL, Sharron M, Lee B, O'Dowd B, Doms RW (1998a). Use of GPR1, GPR15, and STRL33 as coreceptors by diverse human immunodeficiency virus type 1 and simian immunodeficiency virus envelope proteins. Virology 249: $367-378$.

Edinger AL, Hoffman TL, Sharron M, Lee B, Yi Y, Choe W, Kolson DL, Mitrovic B, Zhou Y, Faulds D, Collman RG, Hesselgesser J, Horuk R, Doms RW (1998b). An orphan seven-transmembrane domain receptor expressed widely in the brain functions as a coreceptor for human immunodeficiency virus type 1 and simian immunodeficiency virus. J Virol 72: $7934-7940$.

Edinger AL, Mankowski JL, Doranz BJ, Margulies BJ, Lee B, Rucker J, Sharron M, Hoffman TL, Berson JF, Zink MC, Hirsch VM, Clements JE, Doms RW (1997). CD4independent, CCR5-dependent infection of brain capillary endothelial cells by a neurovirulent simian immunodeficiency virus strain. Proc Natl Acad Sci USA 94: $14742-14747$.

Falangola MF, Hanly A, Galvao-Castro B, Petito CK (1995) HIV infection of human choroid plexus: a possible mechanism of viral entry into the CNS. J Neuropathol Exp Neurol 54: 497-503.

Fantini J, Cook DG, Nathanson N, Spitalnik SL, Gonzalez-Scarano F (1993). Infection of colonic epithelial cell lines by type 1 human immunodeficiency virus is associated with cell surface expression of galactosylceramide, a potential alternative gp120 receptor. Proc Natl Acad Sci USA 90: 2700-2704.

Feng Y, Broder CC, Kennedy PE, Berger EA (1996). HIV1 entry cofactor: functional cDNA cloning of a seventransmembrane, G protein-coupled receptor. Science 272: $872-877$.

Fernandez V, Treutiger CJ, Nash GB, Wahlgren M (1998). Multiple adhesive phenotypes linked to rosetting binding of erythrocytes in Plasmodium falciparum malaria. Infect Immun 66: 2969-2975.

Fiala M, Looney DJ, Stins M, Way DD, Zhang L, Gan X, Chiappelli F, Schweitzer ES, Shapshak P, Weinand M, Graves MC, Witte M, Kim KS (1997). TNF-alpha opens a paracellular route for HIV-1 invasion across the blood-brain barrier. Mol Med 3: 553-564.

Fischer HG, Nitzgen B, Reichmann G, Gross U, Hadding U (1997). Host cells of Toxoplasma gondii encystation in infected primary culture from mouse brain. Parasitol Res 83: 637-641.
Forsyth CB, Plow EF, Zhang L (1998). Interaction of the fungal pathogen Candida albicans with integrin CD11b/CD18: recognition by the I domain is modulated by the lectin-like domain and the CD18 subunit. I Immunol 161: 6198-6205.

Gale CA, Bendel CM, McClellan M, Hauser M, Becker JM, Berman J, Hostetter MK (1998). Linkage of adhesion, filamentous growth, and virulence in Candida albicans to a single gene, INT1. Science 279: $1355-1358$

Gaur NK, Klotz SA (1997). Expression, cloning, and characterization of a Candida albicans gene, ALA1, that confers adherence properties upon Saccharomyces cerevisiae for extracellular matrix proteins. Infect Immun 65: 5289-5294.

Gay-Andrieu F, Cozon GJ, Ferrandiz J, Kahi S, Peyron F (1999). Flow cytometric quantification of Toxoplasma gondii cellular infection and replication. J Parasitol 85: $545-559$.

Geraghty RJ, Krummenacher C, Cohen GH, Eisenberg RJ, Spear PG (1998). Entry of alphaherpesviruses mediated by poliovirus receptor-related protein 1 and poliovirus receptor. Science 280: 1618-1620.

Gomes NG, Boni M, Primo CC (1997). The invasive behaviour of Cryptococcus neoformans: a possibility of direct access to the central nervous system? Mycopathologia 140: 1-11.

Gozalbo D, Gil-Navarro I, Azorin I, Renau-Piqueras J, Martinez JP, Gil ML (1998). The cell wall-associated glyceraldehyde-3-phosphate dehydrogenase of Candida albicans is also a fibronectin and laminin binding protein. Infect Immun 66: 2052-2059.

Greve JM, Davis G, Meyer AM, Forte CP, Yost SC, Marlor CW, Kamarck ME, McClelland A (1989). The major human rhinovirus receptor is ICAM-1. Cell 56: 839847.

Griot C, Gonzalez-Scarano F, Nathanson N (1993). Molecular determinants of the virulence and infectivity of California serogroup bunyaviruses. Annu Rev Microbiol 47: 117-138.

Griot C, Pekosz A, Davidson R, Stillmock K, Hoek M, Lukac D, Schmeidler D, Cobbinah I, Gonzalez-Scarano F, Nathanson N (1994). Replication in cultured C2C12 muscle cells correlates with the neuroinvasiveness of California serogroup bunyaviruses. Virology 201: $399-403$

Haake DA, Lovett MA (1994). Interjunctional invasion of endothelial cell monolayers. Methods Enzymol 236: $447-463$.

Hamilton AJ, Goodley J (1996). Virulence factors of Cryptococcus neoformans. Curr Top Med Mycol 7: $19-42$.

Handunnetti SM, van Schravendijk MR, Hasler T, Barnwell JW, Greenwalt DE, Howard RJ (1992). Involvement of CD36 on erythrocytes as a rosetting receptor for Plasmodium falciparum-infected erythrocytes. Blood 80: 2097-2104.

Harouse JM, Wroblewska Z, Laughlin MA, Hickey WF, Schonwetter BS, Gonzalez-Scarano F (1989). Human choroid plexus cells can be latently infected with human immunodeficiency virus. Ann Neurol 25: $406-411$.

Haywood AM (1974). Characteristics of Senday viru receptors in a model membrane. J Mol Biol 83: $1-5$. 
Hermsen CC, Mommers E, van de Wiel T, Sauerwein RW, Eling WM (1998). Convulsions due to increased permeability of the blood-brain barrier in experimental cerebral malaria can be prevented by splenectomy or anti-T cell treatment. J Infect Dis 178: 1225-1227.

Herndon RM, Johnson RT, Davis LE, Descalzi LR (1974). Ependymitis in mumps virus meningitis: electron microscopic studies of cerebrospinal fluid. Arch Neurol 30: $475-479$.

Hildreth JE, Orentas RJ (1989). Involvement of a leukocyte adhesion receptor (LFA-1) in HIV-induced syncytium formation. Science 244: 1075-1078.

Howard RJ (1988). Malarial proteins at the membrane of Plasmodium falciparum-infected erythrocytes and their involvement in cytoadherence to endothelial cells. Prog Allergy 41: 98-147.

Huang SH, Wass C, Fu Q, Prasadarao NV, Stins M, Kim KS (1995). Escherichia coli invasion of brain microvascular endothelial cells in vitro and in vivo: molecular cloning and characterization of invasion gene ibe10. Infect Immun 63: 4470-4475.

Hurwitz AA, Berman JW, Lyman WD (1994). The role of the blood-brain barrier in HIV infection of the central nervous system. Adv Neuroimmunol 4: 249-256.

Ibrahim AS, Filler SG, Alcouloumre MS, Kozel TR, Edwards Jr JE, Ghannoum MA (1995). Adherence to and damage of endothelial cells by Cryptococcus neoformans in vitro: role of the capsule. Infect Immun 63: $4368-4374$.

Janssen R, Gonzalez-Scarano F, Nathanson N (1984). Mechanisms of bunyavirus virulence. Comparative pathogenesis of a virulent strain of La Crosse and an avirulent strain of Tahyna virus. Lab Invest 50: $447-$ 455.

Janssen RS, Nathanson N, Endres MJ, Gonzalez-Scarano $\mathrm{F}$ (1986). Virulence of La Crosse virus is under polygenic control. J Virol 59: 1-7.

Jaworowicz Jr DJ, Korytko PJ, Singh Lakhman S, Boje KM (1998). Nitric oxide and prostaglandin E2 formation parallels blood-brain barrier disruption in an experimental rat model of bacterial meningitis. Brain Res Bull 46: 541-546.

Jerse AE, Rest RF (1997). Adhesion and invasion by the pathogenic neisseria. Trends Microbiol 5: 217-221.

Johnson RT (1964). Pathogenesis of HSV I virus. Pathways to the nervous system of suckling mice demonstrated by fluorescent antibody staining. J Exp Med 119: $343-356$.

Johnson RT (1982). Viral Infections of Nervous System. Alan R Liss: New York, NY.

Kallstrom H, Liszewski MK, Atkinson JP, Jonsson AB. (1997). Membrane cofactor protein (MCP or CD46) is a cellular pilus receptor for pathogenic Neisseria. Mol Microbiol 25: 639-647.

Kanbe T, Cutler JE (1998). Minimum chemical requirements for adhesin activity of the acid-stable part of Candida albicans cell wall phosphomannoprotein complex. Infect Immun 66: 5812-5818.

Klotz SA, Smith RL (1991). A fibronectin receptor on Candida albicans mediates adherence of the fungus to extracellular matrix. J Infect Dis 163: 604-610.

Kolson DL, Lavi E, Gonzalez-Scarano F (1998). The effects of human immunodeficiency virus in the central nervous system. Adv Virus Res 50: 1-47.
Korhonen TK, Valtonen MV, Parkkinen J, Vaisanen-Rhen V, Finne J, Orskov F, Orskov I, Svenson SB, Makela $\mathrm{PH}$ (1985). Serotypes, hemolysin production, and receptor recognition of Escherichia coli strains associated with neonatal sepsis and meningitis. Infect Immun 48: 486-491.

Lathey JL, Wiley CA, Verity MA, Nelson JA (1990). Cultured human brain capillary endothelial cells are permissive for infection by human cytomegalovirus. Virology 176: $266-273$.

Lavi E, Kolson DL, Ulrich AM, Fu L, Gonzalez-Scarano F (1998). Chemokine receptors in the human brain and their relationship to HIV infection. J Neurovirol 4: $301-311$

Lee SC, Kress Y, Zhao ML, Dickson DW, Casadevall A (1995). Cryptococcus neoformans survive and replicate in human microglia. Lab Invest 73: 871-879.

Lipton HL, Johnson RT (1972). The pathogenesis of rat virus infections in the new born hamster. Lab Invest 27: $508-513$

Lustig S, Danenberg HD, Kafri Y, Kobiler D, Ben-Nathan $D$ (1992). Viral neuroinvasion and encephalitis induced by lipopolysaccharide and its mediators. J Exp Med 176: $707-712$

Macadam AJ, Stone DM, Almond JW, Minor PD (1994). The $5^{\prime}$ noncoding region and virulence of poliovirus vaccine strains. Trends Microbiol 2: 449-454.

Maddon PJ, Dalgleish AG, McDougal JS, Clapham PR, Weiss RA, Axel R (1986). The T4 gene encodes the AIDS virus receptor and is expressed in the immune system and the brain. Cell 47: $333-348$.

Mankowski JL, Spelman JP, Ressetar HG, Strandberg JD, Laterra J, Carter DL, Clements JE, Zink MC (1994). Neurovirulent simian immunodeficiency virus replicates productively in endothelial cells of the central nervous system in vivo and in vitro. J Virol 68: $8202-$ 8208.

McCormick CJ, Craig A, Roberts D, Newbold CI, Berendt AR (1997). Intercellular adhesion molecule-1 and CD36 synergize to mediate adherence of Plasmodium falciparum-infected erythrocytes to cultured human microvascular endothelial cells. J Clin Invest 100: $2521-2529$.

Mendelsohn CL, Wimmer E, Racaniello VR (1989). Cellular receptor for poliovirus: molecular cloning, nucleotide sequence, and expression of a new member of the immunoglobulin superfamily. Cell 56: $855-865$.

Mengaud J, Ohayon H, Gounon P, Mege RM, Cossart P (1996). E-cadherin is the receptor for internalin, a surface protein required for entry of Listeria monocytogenes into epithelial cells. Cell 84: 923-932.

Miller LH, Good MF, Milon G. (1994). Malaria pathogenis. Science 264: 1878-1883.

Montgomery RI, Warner MS, Lum BJ, Spear PG (1996). Herpes simplex virus-1 entry into cells mediated by a novel member of the TNF/NGF receptor family. Cell 87: $427-436$

Morrison LA, Fields BN (1991). Parallel mechanisms in neuropathogenesis of enteric virus infections. J Virol 65: $2767-2772$. 
Morrison LA, Sidman RL, Fields BN (1991). Direct spread of reovirus from the intestinal lumen to the central nervous system through vagal autonomic nerve fibers. Proc Natl Acad Sci USA 88: 3852-3856.

Moses AV, Bloom FE, Pauza CD, Nelson JA (1993). Human immunodeficiency virus infection of human brain capillary endothelial cells occurs via a CD4/ galactosylceramide-independent mechanism. Proc Natl Acad Sci USA 90: 10474-10478.

Moses AV, Stenglein SG, Strussenberg JG, Wehrly K, Chesebro B, Nelson JA (1996). Sequences regulating tropism of human immunodeficiency virus type 1 for brain capillary endothelial cells map to a unique region on the viral genome. J Virol 70: 3401-3406.

Mun-Bryce S, Rosenberg GA (1998). Gelatinase B modulates selective opening of the blood-brain barrier during inflammation. Am J Physiol 274: R1203R1211.

Murphy FA (1977). Rabies pathogenesis: a brief review. Arch Virol 54: 279-297.

Nizet V, Kim KS, Stins M, Jonas M, Chi EY, Nguyen D, Rubens CE (1997). Invasion of brain microvascular endothelial cells by Group B streptococci. Infect Immun 65: $5074-5081$.

Nottet HS, Persidsky Y, Sasseville VG, Nukuna AN, Bock P, Zhai QH, Sharer LR, McComb RD, Swindells S, Soderland C, Gendelman HE (1996). Mechanisms for the transendothelial migration of HIV-1-infected monocytes into brain. J Immunol 156: 1284-1295.

Ockenhouse CF, Betageri R, Springer TA, Staunton DE (1992a). Plasmodium falciparum-infected erythrocytes bind ICAM-1 at a site distinct from LFA-1, Mac-1, and human rhinovirus. Cell 68: 63-69.

Ockenhouse CF, Tegoshi T, Maeno Y, Benjamin C, Ho M, Kan KE, Thway Y, Win K, Aikawa M, Lobb RR (1992b). Human vascular endothelial cell adhesion receptors for Plasmodium falciparum-infected erythrocytes: roles for endothelial leukocyte adhesion molecule 1 and vascular cell adhesion molecule 1. J Exp Med 176: $1183-1189$.

Odds FC (1988). Candida and Candidosis. W.B. Saunders: London.

Overturf GD (1994). Bacterial Meningitis. 5th edn. In: Infectious Diseases. Hoeprich PD, Jordan MC, Rondald AR (eds). J.B. Lippincott Company: Philadelphia, pp. 1107-1124.

Parida SK, Domann E, Rohde M, Muller S, Darji A, Hain $\mathrm{T}$, Wehland J, Chakraborty $\mathrm{T}$ (1998). Internalin $\mathrm{B}$ is essential for adhesion and mediates the invasion of Listeria monocytogenes into human endothelial cells. Mol Microbiol 28: 81-93.

Parkkinen J, Korhonen TK, Pere A, Hacker J, Soinila S (1988). Binding sites in the rat brain for Escherichia coli S fimbriae associated with neonatal meningitis. $J$ Clin Invest 81: 860-865.

Pathak S, Webb HE (1974). Possible mechanisms for the transport of Semiliki Forest virus into and within mouse brain: an electron microscopic study. J Neurol Sci 23: $175-184$.

Patrick D, Betts J, Frey EA, Prameya R, Dorovini-Zis K, Finlay BB (1992). Haemophilus influenzae lipopolysaccharide disrupts confluent monolayers of bovine brain endothelial cells via a serum-dependent cytotoxic pathway. J Infect Dis 165: 865-872.
Pekosz A, Griot C, Stillmock K, Nathanson N, GonzalezScarano F (1995). Protection from La Crosse virus encephalitis with recombinant glycoproteins: role of neutralizing anti-G1 antibodies. J Virol 69: 34753481.

Peluso R, Haase A, Stowring L, Edwards M, Ventura P (1985). A Trojan Horse mechanism for the spread of visna virus in monocytes. Virology 147: 231-236.

Persidsky Y, Stins M, Way D, Witte MH, Weinand M, Kim KS, Bock P, Gendelman HE, Fiala M (1997). A model for monocyte migration through the bloodbrain barrier during HIV-1 encephalitis. J Immunol 158: $3499-3510$.

Pleskoff O, Treboute C, Brelot A, Heveker N, Seman M, Alizon $M$ (1997). Identification of a chemokine receptor encoded by human cytomegalovirus as a cofactor for HIV-1 entry. Science 276: 1874-1878.

Polder TW, Eling WM, Curfs JH, Jerusalem CR, WijersRouw M (1992). Ultrastructural changes in the bloodbrain barrier of mice infected with Plasmodium berghei. Acta Leiden 60: 31-46.

Prasadarao NV, Wass CA, Hacker J, Jann K, Kim KS (1993). Adhesion of S-fimbriated Escherichia coli to brain glycolipids mediated by $s f a A$ gene-encoded protein of S-fimbriae. J Biol Chem 268: 10356-10363.

Prasadarao NV, Wass CA, Huang SH, Kim KS (1999). Identification and characterization of a novel Ibe10 binding protein that contributes to Escherichia coli invasion of brain microvascular endothelial cells. Infect Immun 67: 1131-1138.

Prasadarao NV, Wass CA, Kim KS (1996a). Endothelial cell GlcNAc beta 1-4GlcNAc epitopes for outer membrane protein A enhance traversal of Escherichia coli across the blood-brain barrier. Infect Immun 64: $154-160$

Prasadarao NV, Wass CA, Weiser JN, Stins MF, Huang SH, Kim KS (1996b). Outer membrane protein A of Escherichia coli contributes to invasion of brain microvascular endothelial cells. Infect Immun 64: $146-153$

Pron B, Taha MK, Rambaud C, Fournet JC, Pattey N, Monnet JP, Musilek M, Beretti JL, Nassif X (1997). Interaction of Neisseria meningitidis with the components of the blood-brain barrier correlates with an increased expression of PilC. I Infect Dis 176: 12851292.

Rambukkana A, Salzer JL, Yurchenco PD, Tuomanen EI (1997). Neural targeting of Mycobacterium leprae mediated by the $\mathrm{G}$ domain of the laminin-alpha 2 chain. Cell 88: 811-821.

Rambukkana A, Yamada H, Zanazzi G, Mathus T, Salzer JL, Yurchenco PD, Campbell KP, Fischetti VA (1998). Role of alpha-dystroglycan as a Schwann cell receptor for Mycobacterium leprae. Science 282: 2076-2079.

Reagan KJ, Wunner WH (1985). Rabies virus interaction with various cell lines is independent of the acetylcholine receptor. Arch Virol 84: 277-282.

Reeder JC, Cowman AF, Davern KM, Beeson JG, Thomspon JK, Rogerson SJ, Brown GV (1999). The adhesion of Plasmodium falciparum-infected erythrocytes to chondroitin sulfate A is mediated by Plasmodium falciparum erythrocyte membrane protein 1 . Proc Natl Acad Sci USA 96: 5198-5202. 
Reese TS, Karnovsky MJ (1968). Fine structural localization of a blood-brain barrier to exogenous peroxidase. J Cell Biol 34: $207-217$.

Ring A, Tuomanen EI (1997). Targeting bacteria to the central nervous system. In: Defense of the Brain. Peterson PK, Remington JS (eds). Blackwell Science: Malden, pp. 90-106.

Ring A, Weiser JN, Tuomanen EI (1998). Pneumococcal trafficking across the blood-brain barrier. Molecular analysis of a novel bidirectional pathway. J Clin Invest 102: $347-360$.

Robert C, Pouvelle B, Meyer P, Muanza K, Fujioka H, Aikawa M, Scherf A, Gysin J (1995). Chondroitin-4sulphate (proteoglycan), a receptor for Plasmodium falciparum-infected erythrocyte adherence on brain microvascular endothelial cells. Res Immunol 146: $383-393$

Roberts DD, Sherwood JA, Spitalnik SL, Panton LJ, Howard RJ, Dixit VM, Frazier WA, Miller LH, Ginsburg V (1985). Thrombospondin binds falciparum malaria parasitized erythrocytes and may mediate cytoadherence. Nature 318: 64-66.

Rogerson SJ, Chaiyaroj SC, Ng K, Reeder JC, Brown GV (1995). Chondroitin sulfate A is a cell surface receptor for Plasmodium falciparum-infected erythrocytes. J Exp Med 182: 15-20.

Rosenow C, Ryan P, Weiser JN, Johnson S, Fontan P, Ortquist A, Masure HR (1997). Contribution of novel chlorine-binding proteins to adherence, colonozation and immunogenicity of Streptococcus pneumoniae. Mol Microbiol 25, 819-825.

Rowe JA, Moulds JM, Newbold CI, Miller LH (1997). Plasmodium falciparum rosetting mediated by a parasite-variant erythrocyte membrane protein and complement-receptor 1. Nature 388: 292-295.

Rziha HJ, Mettenleiter TC, Ohlinger V, Wittmann G (1986). Herpesvirus (pseudorabies virus) latency in swine: occurrence and physical state of viral DNA in neural tissues. Virology 155: 600-613.

Sasseville VG, Lane JH, Walsh D, Ringler DJ, Lackner AA (1995). VCAM-1 expression and leukocyte trafficking to the CNS occur early in infection with pathogenic isolates of SIV. J Med Primatol 24: 123-131.

Sasseville VG, Newman W, Brodie SJ, Hesterberg P, Pauley D, Ringler DJ (1994). Monocyte adhesion to endothelium in simian immunodeficiency virus-induced AIDS encephalitis is mediated by vascular cell adhesion molecule-1/alpha 4 beta 1 integrin interactions. Am J Pathol 144: 27-40.

Schmidtmayerova $H$, Nottet HS, Nuovo G, Raabe T, Flanagan CR, Dubrovsky L, Gendelman HE, Cerami A, Bukrinsky M, Sherry B (1996). Human immunodeficiency virus type 1 infection alters chemokine beta peptide expression in human monocytes: implications for recruitment of leukocytes into brain and lymph nodes. Proc Natl Acad Sci USA 93: 700-704.

Shrikant P, Benos DJ, Tang LP, Benveniste EN (1996). HIV glycoprotein 120 enhances intercellular adhesion molecule-1 gene expression in glial cells. Involvement of Janus kinase/signal transducer and activator of transcription and protein kinase C signaling pathways. J Immunol 156: 1307-1314.

Sibley LD (1995). Invasion of vertebrate cells by Toxoplasma gondii. Trends Cell Biol 5: 129-132.
Skinner MA, Racaniello VR, Dunn G, Cooper J, Minor PD, Almond JW (1989). New model for the secondary structure of the $5^{\prime}$ non-coding RNA of poliovirus is supported by biochemical and genetic data that also show that RNA secondary structure is important in neurovirulence. J Mol Biol 207: 379-392.

Smith JD, Chitnis CE, Craig AG, Roberts DJ, HudsonTaylor DE, Peterson DS, Pinches R, Newbold CI, Miller LH (1995). Switches in expression of Plasmodium falciparum var genes correlate with changes in antigenic and cytoadherent phenotypes of infected erythrocytes. Cell 82: 101-110.

Soilu-Hanninen M, Roytta M, Salmi AA, Salonen R (1997). Semliki Forest virus infection leads to increased expression of adhesion molecules on splenic T-cells and on brain vascular endothelium. $J$ Neurovirol 3: 350-360.

Spellerberg B, Prasad S, Cabellos C, Burroughs M, Cahill P, Tuomanen E (1995). Penetration of the blood-brain barrier: enhancement of drug delivery and imaging by bacterial glycopeptides. J Exp Med 182: 1037-1043.

Spreghini E, Gismondi A, Piccoli M, Santoni G (1999). Evidence for alphavbeta3 and alphavbeta5 integrinlike vitronectin (VN) receptors in Candida albicans and their involvement in yeast cell adhesion to VN. $J$ Infect Dis 180: 156-166.

Staab JF, Bradway SD, Fidel PL, Sundstrom P (1999). Adhesive and mammalian transglutaminase substrate properties of Candida albicans Hwp1. Science 283: $1535-1538$.

Stins MF, Prasadarao NV, Ibric L, Wass CA, Luckett P, Kim KS (1994). Binding characteristics of $S$ fimbriated Escherichia coli to isolated brain microvascular endothelial cells. Am J Pathol 145: 1228-1236.

Strauss JH, Strauss EG (1994). The alphaviruses: gene expression, replication, and evolution. Microbiol Rev 58: $491-562$

Su XZ, Heatwole VM, Wertheimer SP, Guinet F, Herrfeldt JA, Peterson DS, Ravetch JA, Wellems TE (1995). The large diverse gene family var encodes proteins involved in cytoadherence and antigenic variation of Plasmodium falciparum-infected erythrocytes. Cell 82: 89-100.

Summer BA, Griesen HA, Apper MG (1978). Possible initiation of viral encephalomyelitis in dogs by migrating lymphocytes infected with distemper. Lancet 1: $187-189$.

Superti F, Hauttecoeur B, Morelec MJ, Goldoni P, Bizzini $B$, Tsiang $H$ (1986). Involvement of gangliosides in rabies virus infection. J Gen Virol 67: 47-56.

Szczepanski A, Furie MB, Benach JL, Lane BP, Fleit HB (1990). Interaction between Borrelia burgdorferi and endothelium in vitro. J Clin Invest 85: 1637-1647.

Temesvari P, Abraham CS, Speer CP, Kovacs J, Megyeri P (1993). Escherichia coli 0111 B4 lipopolysaccharide given intracisternally induces blood-brain barrier opening during experimental neonatal meningitis in piglets. Pediatr Res 34: 182-186.

Thomas DD, Navab M, Haake DA, Fogelman AM, Miller JN, Lovett MA (1988) Treponema pallidum invades intercellular junctions of endothelial cell monolayers. Proc Natl Acad Sci USA 85: 3608-3612. 
Thoulouze MI, Lafage M, Schachner M, Hartmann U, Cremer H, Lafon $M$ (1998). The neural cell adhesion molecule is a receptor for rabies virus. J Virol 72: $7181-7190$.

Thumwood CM, Hunt NH, Clark IA, Cowden WB (1988). Breakdown of the blood-brain barrier in murine cerebral malaria. Parasitology 96: 579-589.

Timpel C, Strahl-Bolsinger S, Ziegelbauer K, Ernst JF (1998). Multiple functions of Pmt1p-mediated protein O-mannosylation in the fungal pathogen Candida albicans. J Biol chem 273: $20837-20846$.

Treutiger CJ, Heddini A, Fernandez V, Muller WA, Wahlgren M (1997). PECAM-1/CD31, an endothelial receptor for binding Plasmodium falciparum-infected erythrocytes. Nat Med 3: 1405-1408.

Tucker PC, Strauss EG, Kuhn RJ, Strauss JH, Griffin DE (1993). Viral determinants of age-dependent virulence of Sindbis virus for mice. J Virol 67: 4605-4610.

Tuffereau C, Benejean J, Blondel D, Kieffer B, Flamand A (1998). Low-affinity nerve-growth factor receptor (P75NTR) can serve as a receptor for rabies virus. EMBO J 17: 7250-7259.

Tuomanen E (1996). Entry of pathogens into the central nervous system. FEMS Microbiol Rev 18: 289-299.

Tuomanen EI, Masure HR (1997). Molecular and cellular biology of pneumococcal infection. Microb Drug Resist 3: 297-308.

Turner BG, Summers MF (1999). Structural biology of HIV. J Mol Biol 285: 1-32.

Tyler KL, Gonzalez-Scarano F (1997). Viral diseases of the central nervous system. In: Viral Pathogenesis. Nathanson N, Ahmed R, Gonzalez-Scarano F, Griffin DE, Holmes KV, Murphy FA, Robinson HL (eds). Lippincott-Raven Publishers: Philadelphia, pp. 837853.

Virji M, Makepeace K, Ferguson DJ, Watt SM (1996a). Carcinoembryonic antigens (CD66) on epithelial cells and neutrophils are receptors for Opa proteins of pathogenic neisseriae. Mol Microbiol 22: 941-950.

Virji M, Makepeace K, Moxon ER (1994). Distinct mechanisms of interactions of Opc-expressing meningococci at apical and basolateral surfaces of human endothelial cells; the role of integrins in apical interactions. Mol Microbiol 14: 173-184.
Virji M, Watt SM, Barker S, Makepeace K, Doyonnas R (1996b). The N-domain of the human CD66a adhesion molecule is a target for Opa proteins of Neisseria meningitidis and Neisseria gonorrhoeae. Mol Microbiol 22: 929-939.

Wang KS, Kuhn RJ, Strauss EG, Ou S, Strauss JH (1992). High-affinity laminin receptor is a receptor for Sindbus virus in mammalian cells. $J$ Virol 66: $4992-5001$.

Warner MS, Geraghty RJ, Martinez WM, Montgomery RI, Whitbeck JC, Xu R, Eisenberg RJ, Cohen GH, Spear PG (1998). A cell surface protein with herpesvirus entry activity (HveB) confers susceptibility to infection by mutants of herpes simplex virus type 1, herpes simplex virus type 2 , and pseudorabies virus. Virology 246: $179-189$.

Weiser JN, Austrian R, Sreenivasan PK, Masure HR (1994). Phase variation in pneumococcal opacity: relationship between colonial morphology and nasopharyngeal colonization. Infect Immun 62: 25822589.

Wilson SL, Drevets DA (1998). Listeria monocytogenes infection and activation of human brain microvascular endothelial cells. J Infect Dis 178: 1658-1666.

Wispelwey B, Hansen EJ, Scheld WM (1989). Haemophilus influenzae outer membrane vesicle-induced blood-brain barrier permeability during experimental meningitis. Infect Immun 57: 2559-2562.

Wispelwey B, Lesse AJ, Hansen EJ, Scheld WM (1988). Haemophilus influenzae lipopolysaccharide-induced blood brain barrier permeability during experimental meningitis in the rat. J Clin Invest 82: 1339-1346.

Wunner WH, Reagan KJ, Koprowski H (1984). Characterization of saturable binding sites for rabies virus. $J$ Virol 50: $691-697$.

Zeuthen T, Wright EM (1981). Epithelial potassium transport: tracer and electrophysiological studies in choroid plexus. J Memb Biol 60: 105-128.

Zurbriggen A, Fujinami RS (1988). Theiler's virus infection in nude mice: viral RNA in vascular endothelial cells. J Virol 62: 3589-3596. 